Published in final edited form as:

Life Sci. 2006 March 27; 78(18): 2088-2098.

\title{
Tocotrienols: Vitamin E Beyond Tocopherols
}

\author{
Chandan K. Sen, Savita Khanna, and Sashwati Roy \\ Laboratory of Molecular Medicine, Department of Surgery, Davis Heart \& Lung Research Institute, \\ The Ohio State University Medical Center, Columbus, Ohio 43210
}

\begin{abstract}
In nature, eight substances have been found to have vitamin $E$ activity: $\alpha-, \beta-, \gamma$ - and $\delta$-tocopherol; and $\alpha-, \beta-, \gamma$ - and $\delta$-tocotrienol. Yet, of all papers on vitamin E listed in PubMed less than $1 \%$ relate to tocotrienols. The abundance of $\alpha$-tocopherol in the human body and the comparable efficiency of all vitamin $\mathrm{E}$ molecules as antioxidants, led biologists to neglect the non-tocopherol vitamin $\mathrm{E}$ molecules as topics for basic and clinical research. Recent developments warrant a serious reconsideration of this conventional wisdom. Tocotrienols possess powerful neuroprotective, anticancer and cholesterol lowering properties that are often not exhibited by tocopherols. Current developments in vitamin $E$ research clearly indicate that members of the vitamin $E$ family are not redundant with respect to their biological functions. $\alpha$-Tocotrienol, $\gamma$-tocopherol, and $\delta$-tocotrienol have emerged as vitamin E molecules with functions in health and disease that are clearly distinct from that of $\alpha$-tocopherol. At nanomolar concentration, $\alpha$-tocotrienol, not $\alpha$-tocopherol, prevents neurodegeneration. On a concentration basis, this finding represents the most potent of all biological functions exhibited by any natural vitamin E molecule. An expanding body of evidence support that members of the vitamin $\mathrm{E}$ family are functionally unique. In recognition of this fact, title claims in manuscripts should be limited to the specific form of vitamin E studied. For example, evidence for toxicity of a specific form of tocopherol in excess may not be used to conclude that high-dosage "vitamin E" supplementation may increase all-cause mortality. Such conclusion incorrectly implies that tocotrienols are toxic as well under conditions where tocotrienols were not even considered. The current state of knowledge warrants strategic investment into the lesser known forms of vitamin $\mathrm{E}$. This will enable prudent selection of the appropriate vitamin E molecule for studies addressing a specific need.
\end{abstract}

\section{Keywords}

antioxidant; redox; nutrient; supplement; neuroprotection

\section{Introduction to Vitamine and Vitamin E}

In 1905, Englishman William Fletcher determined that if special factors (vitamins) were removed from food disease ensued. Fletcher was researching the causes of the disease Beriberi when he discovered that eating unpolished rice prevented Beriberi and eating polished rice did not. William Fletcher believed that there were special nutrients contained in the husk of the rice. Next year, English biochemist Sir Frederick Gowland Hopkins also discovered that certain food factors were important to health. In 1912, Polish scientist Cashmir Funk named the special nutritional parts of food as a "vitamine" after "vita" meaning life and "amine" from compounds found in the thiamine he isolated from rice husks. Vitamine was later shortened to vitamin when it was discovered that not all of the vitamins contain nitrogen, and, therefore, not all are

Corresponding Author: Professor Chandan K. Sen, 512 Davis Heart \& Lung Research Institute, 473 West $12^{\text {th }}$ Avenue, The Ohio State University Medical Center, Columbus, Ohio 43210, Tel. 614247 7658, Fax 614247 7818, sen-1 @ medctr.osu.edu. 
amines. Together, Hopkins and Funk formulated the vitamin hypothesis of deficiency disease - that a lack of vitamins could make people sick. Vitamin E was discovered in 1922 in green leafy vegetables by University of California researchers, Herbert Evans and Katherine Bishop. In 1924, Sure named it vitamin E. Because E supported fertility, it was scientifically named tocopherol. This comes from the Greek word tokos meaning childbirth, and phero meaning to bring forth, and the $o l$ ending was added to indicate the alcohol properties of this molecule. In 1936 it was discovered that vitamin $\mathrm{E}$ was abundant in wheat germ oil. Two years later, it was chemically synthesized for the first time. The U.S. National Research Council sponsored studies on deficiencies of vitamin $\mathrm{E}$, and based on the results $\mathrm{E}$ was designated an essential vitamin. Vitamin E emerged as an essential, fat-soluble nutrient that functions as an antioxidant in the human body. It is essential, because the body cannot manufacture its own vitamin $\mathrm{E}$ and foods and supplements must provide it. Since the elucidation of the chemical structure of vitamin $E$ in 1938 by Fenholz and the synthesis of $d l$ - $\alpha$-tocopherol by Karrer in the same year, specific focus was directed on the chemical class of natural compounds that qualify to be vitamin E. At present, vitamin E represents a generic term for all tocopherols and their derivatives having the biological activity of RRR- $\alpha$-tocopherol, the naturally occurring stereoisomer compounds with vitamin E activity (Traber and Packer, 1995; Traber and Sies, 1996). In nature, eight substances have been found to have vitamin $E$ activity: $\alpha-, \beta-, \gamma$ - and $\delta$-tocopherol; and $\alpha-, \beta$-, $\gamma$ - and $\delta$-tocotrienol (Figure 1). Yet, of the $24000+$ papers on vitamin E listed in PubMed, only just over 200 relate to tocotrienols (Table 1). The current handicap in knowledge of how tocotrienols may be implicated in human health and disease and the significance of filling that void in vitamin $\mathrm{E}$ research is discussed in this minireview.

\section{Biosynthesis of tocopherols and tocotrienols}

Vitamin E are essential components of the human diet and are synthesized exclusively by photosynthetic organisms. Tocopherols consist of a chromanol ring and a 15-carbon tail derived from homogentisate (HGA) and phytyl diphosphate, respectively (Fig. 1).

Condensation of HGA and phytyl diphosphate, the committed step in tocopherol biosynthesis, is catalyzed by HGA phytyltransferase (HPT). Tocotrienols differ structurally from tocopherols by the presence of three trans double bonds in the hydrocarbon tail (Fig. 1). Tocotrienols are the primary form of vitamin $\mathrm{E}$ in the seed endosperm of most monocots, including agronomically important cereal grains such as wheat, rice, and barley. Tocotrienols are also found in the seed endosperm of a limited number of dicots, including Apiaceae species and certain Solanaeceae species, such as tobacco. These molecules are found only rarely in vegetative tissues of plants. Crude palm oil extracted from the fruits of Elaeis guineensis particularly contains a high amount of tocotrienols (up to $800 \mathrm{mg} / \mathrm{kg}$ ), mainly consisting of $\gamma$ tocotrienol and $\alpha$-tocotrienol. Tocopherols, by contrast, occur ubiquitously in plant tissues and are the exclusive form of vitamin $\mathrm{E}$ in leaves of plants and seeds of most dicots. Transgenic expression of the barley HGGT (homogentisic acid transferase, which catalyzes the committed step of tocotrienol biosynthesis) in Arabidopsis thaliana leaves resulted in accumulation of tocotrienols, which were absent from leaves of nontransformed plants, and a 10- to 15-fold increase in total vitamin E antioxidants (tocotrienols plus tocopherols). Overexpression of the barley HGGT in corn seeds resulted in an increase in tocotrienol and tocopherol content of as much as six-fold. These results provide insight into the genetic basis for tocotrienol biosynthesis in plants and demonstrate the ability to enhance the antioxidant content of crops by introduction of an enzyme that redirects metabolic flux (Cahoon et al., 2003). Recently, another strategy involving genetic engineering of metabolic pathways in plants has proved to be efficient in bolstering tocotrienol biosynthesis (Rippert et al., 2004). In plants, phenylalanine is the precursor of a myriad of secondary compounds termed phenylpropanoids. In contrast, much less carbon is incorporated into tyrosine that provides p-hydroxyphenylpyruvate and homogentisate, the aromatic precursors of vitamin E. The flux of these two compounds has been upregulated by deriving their synthesis directly at the level of prephenate. This was 
achieved by the expression of the yeast prephenate dehydrogenase gene in tobacco plants that already overexpress the Arabidopsis p-hydroxyphenylpyruvate dioxygenase coding sequence. A massive accumulation of tocotrienols was observed in leaves. These molecules, which were undetectable in wild-type leaves, became the major forms of vitamin $\mathrm{E}$ in the leaves of the transgenic lines. An increased resistance of the transgenic plants toward the herbicidal phydroxyphenylpyruvate dioxygenase inhibitor diketonitril was also observed. Thus, the synthesis of p-hydroxyphenylpyruvate is a limiting step for the accumulation of vitamin $\mathrm{E}$ in plants (Rippert et al., 2004).

\section{Tocotrienols: A cameo role in the side-lines of tocopherol celebrity}

Often, the term vitamin $E$ is synonymously used with $\alpha$-tocopherol. While the expression is correct it is incomplete and may be often misleading. $d-\alpha$-Tocopherol (RRR- $\alpha$-tocopherol) has the highest bioavailability and is the standard against which all the others must be compared. However, it is only one out of eight natural forms of vitamin E. Tocotrienols, formerly known as $\zeta, \varepsilon$ or $\eta$-tocopherols (Fig. 1), are similar to tocopherols except that they have an isoprenoid tail with three unsaturation points instead of a saturated phytyl tail (Fig. 1). Interestingly, tocotrienols possess powerful neuroprotective, antioxidant, anti-cancer and cholesterol lowering properties that often differ from the properties of tocopherols (Table 1). Micromolar amounts of tocotrienol suppress the activity of HMG-CoA reductase, the hepatic enzyme responsible for cholesterol synthesis (Pearce et al., 1994;Pearce et al., 1992). Tocotrienols are thought to have more potent antioxidant properties than $\alpha$-tocopherol (Serbinova et al., 1991; Serbinova and Packer, 1994). The unsaturated side chain of tocotrienol allows for more efficient penetration into tissues that have saturated fatty layers such as the brain and liver (Suzuki et al., 1993). Experimental research examining the antioxidant, free radical scavenging effects of tocopherol and tocotrienols revealed that tocotrienols appear superior due to their better distribution in the fatty layers of the cell membrane (Suzuki et al., 1993). One major justification often used to side-line tocotrienol research is the relative inferiority of the bioavailability of orally taken tocotrienols compared to that of $\alpha$-tocopherol. The hepatic $\alpha$ tocopherol transfer protein ( $\alpha$-TTP), together with the tocopherol-associated proteins (TAP) is responsible for the endogenous accumulation of natural $\alpha$-tocopherol. Although these systems have a much lower affinity to transport tocotrienols, it has been evident that orally supplemented tocotrienol results in plasma tocotrienol concentration in the range of $1 \mu \mathrm{M}$ (O'Byrne et al., 2000). Of note, such circulating levels of $\alpha$-tocotrienol are almost an order of magnitude higher than that required to protect neurons against a range of neurotoxic insults (Khanna et al., 2003;Sen et al., 2000). Despite such promising potential, tocotrienol research accounts for less than $1 \%$ of all vitamin $E$ research published in PubMed. The unique vitamin action of $\alpha$-tocopherol, combined with its prevalence in the human body and the similar efficiency of tocopherols as chain-breaking antioxidants, led biologists to almost completely discount the "minor" vitamin E molecules as topics for basic and clinical research. Recent discoveries have forced a serious reconsideration of this conventional wisdom (Hensley et al., 2004).

\section{$\alpha$-Tocopherol: Riding the wave for five decades}

In 1950, Kamimura's treatment of frostbite using $\alpha$-tocopherol represents one of the earliest therapeutic applications of the vitamin (Kamimura, 1977). Early works of Tappel identified that $\alpha$-tocopherol effectively inhibits biological oxidation processes (Tappel, 1953, 1954, 1955; Zalkin and Tappel, 1960; Zalkin et al., 1960). It was soon realized that tocopherol deficiency in humans led to elevated levels of oxidative lipid damage and erythrocyte hemolysis (Horwitt et al., 1956). These observations set the stage for the emergence of tocopherol as a biological antioxidant (Green and Bunyan, 1969), a concept that drew widespread attention in the decades to follow. Two decades after the "biological antioxidant 
theory" (Green and Bunyan, 1969) was reported, Burton and Ingold presented the first comprehensive review article discussing that $\alpha$-tocopherol has near optimal activity as a chainbreaking antioxidant and that both the phenolic head and phytyl tails contributed to the biological properties of the vitamin E molecule (Burton and Ingold, 1989). $\alpha$-Tocopherol gained recognition as the most important lipophilic radical-chain-breaking antioxidant in tissues in vivo. Deficiency of $\alpha$-tocopherol in membranes made them highly permeable and therefore vulnerable to degradation. Tocopherols seemed also to influence other important biophysical membrane characteristics, such as fluidity, in a manner similar to that of cholesterol. Studies of the antioxidant properties led to the recognition that during the reaction of $\alpha$-tocopherol with an appropriate oxidizing species, $\alpha$-tocopherol may be oxidized to $\alpha$ tocopheryl quinine (Seward et al., 1969). In latter studies where peroxidizing lipids were used to induce the formation of antioxidant radicals, electron spin resonance spectroscopy revealed that free radical interactions of $d l$ - $\alpha$-tocopherol generate $d l$ - $\alpha$-tocopheroxyl radicals. It was thus realized that $\alpha$-tocopherol is only available as an antioxidant for a short period of time (Lambelet and Loliger, 1984). Importantly, it was noted that the reaction kinetics and stability of the four tocopherols were not identical. The fast reacting $d l$ - $\alpha$-tocopherol reacted more rapidly and trapped free radicals more thoroughly and was therefore only available as an antioxidant for a short period of time as compared with the slowly reacting $d l-\delta$-tocopherol. $d l-\beta$ - and $d l-\gamma$-Tocopherols behaved in an intermediate way (Lambelet and Loliger, 1984). That ascorbate can transfer hydrogen to $\alpha$-tocopheroxyl radicals and thus regenerate $\alpha$-tocopherol (Bascetta et al., 1983) encouraged the concept of antioxidant recycling. Mass analysis studies demonstrated that tocopherol can be regenerated in human cell homogenates implying that maintenance of membrane tocopherol status may be an essential function of ascorbate and GSH which operate in concert to ensure maximum membrane protection against oxidative damage (Chan et al., 1991). While the concept of antioxidant recycling was extended to build the "antioxidant network" hypothesis (Packer and Suzuki, 1993), skepticism regarding whether such interactions take place in vivo stirred the field (Strain and Mulholland, 1992). In the late eighties, the discovery that oxidative modification of low-density lipoprotein is a key trigger for atherosclerosis represented a major breakthrough in biomedical research. The early nineties was thus a time when numerous laboratories studied mechanisms underlying the oxidation of LDL and the inhibition of such oxidation. Because $\alpha$-tocopherol was identified as the major antioxidant present in human lipoproteins, it received much attention as a suppressor of LDL lipid oxidation and as an epidemiological marker for ischemic heart disease. While most laboratories were excited about $\alpha$-tocopherol preventing LDL oxidation, Stocker et al published conditions under which $\alpha$-tocopherol may actually act as a pro-oxidant via the $\alpha$-tocopheroxyl radical (Bowry et al., 1995). This direct link established between vitamin $\mathrm{E}$ chemistry and health outcomes drew significant attention underscoring the potential adverse effects of redoxactive antioxidant nutrients. Although the relevance of the proposed antioxidant network remained to be proven in in vivo systems, enthusiasm for therapeutic regimens including multiple antioxidant members of the network soared (Albanes et al., 1996; DeCosse et al., 1989; Fuchs and Kern, 1998; Hartman et al., 1998; Liede et al., 1998; McKeown-Eyssen et al., 1988; Mireles-Rocha et al., 2002; Porkkala-Sarataho et al., 2000; Rapola et al., 1998; Rapola et al., 1997; Salonen et al., 2000; Teikari et al., 1998; Teikari et al., 1997; Woodson et al., 1999) resulting in quite a few clinical trials at a time when basic scientists were still trying to grasp the fundamentals.

\section{Functional uniqueness of vitamin E family members: Caution against empirical claims}

All eight tocols in the vitamin E family share close structural similarity (Fig. 1) and hence comparable antioxidant efficacy (Table 1). Yet, current studies of the biological functions of vitamin $E$ continue to indicate that members in the vitamin $\mathrm{E}$ family possess unique biological 
functions often not shared by other family members. One of the earliest observations suggesting that $\alpha$-tocopherol may have functions independent of its antioxidant property came from the study of platelet adhesion. $\alpha$-Tocopherol strongly inhibits platelet adhesion. Doses of $400 \mathrm{IU} /$ day provide greater than $75 \%$ inhibition of platelet adhesion to a variety of adhesive proteins when tested at low shear rate in a laminar flow chamber. The antiadhesive effect of $\alpha$-tocopherol appeared to be related to a reduction in the number and size of pseudopodia upon platelet activation and led to the hypothesis that within the body vitamin $\mathrm{E}$ may exert functions beyond its antioxidant property (Steiner, 1993). That members of the tocopherol family may have functions independent of their antioxidant properties gained more prominence when vitamin E molecules with comparable antioxidant properties exhibited contrasting biological effects (Boscoboinik et al., 1991). At the posttranslational level, $\alpha$-tocopherol inhibits protein kinase $\mathrm{C}, 5$-lipoxygenase and phospholipase $\mathrm{A} 2$ and activates protein phosphatase $2 \mathrm{~A}$ and diacylglycerol kinase. Some genes (e.g. scavenger receptors, $\alpha$-TTP, $\alpha$-tropomyosin, matrix metalloproteinase-19 and collagenase) are specifically modulated by $\alpha$-tocopherol at the transcriptional level. $\alpha$-Tocopherol also inhibits cell proliferation, platelet aggregation and monocyte adhesion. These effects have been characterized to be unrelated to the antioxidant activity of vitamin $\mathrm{E}$, and possibly reflect specific interactions of $\alpha$-tocopherol with enzymes, structural proteins, lipids and transcription factors (Zingg and Azzi, 2004). $\gamma$-Tocopherol represents the major form of vitamin E in the diet in the USA, but not in Europe. Desmethyl tocopherols, such as $\gamma$-tocopherol and specific tocopherol metabolites, most notably the carboxyethyl-hydroxychroman (CEHC) products, exhibit functions that are not shared by $\alpha$ tocopherol. The activities of these other tocopherols do not map directly to their chemical antioxidant behavior but rather reflect anti-inflammatory, antineoplastic, and natriuretic functions possibly mediated through specific binding interactions (Hensley et al., 2004). Metabolites of $\gamma$-tocopherol (2,7,8-trimethyl-2-(beta-carboxyethyl)-6-hydroxychroman), but not that of $\alpha$-tocopherol, provides natriuretic activity. Moreover, a nascent body of epidemiological data suggests that $\gamma$-tocopherol is a better negative risk factor for certain types of cancer and myocardial infarction than is $\alpha$-tocopherol (Wagner et al., 2004). Further evidence supporting the unique biological significance of vitamin $\mathrm{E}$ family members is provided by current results derived from $\alpha$-tocotrienol research. As illustrated in Table $1, \alpha$ tocotrienol possesses numerous functions that are not shared by $\alpha$-tocopherol. For example, nanomolar concentrations of $\alpha$-tocotrienol uniquely prevents inducible neurodegeneration by regulating specific mediators of cell death (Khanna et al., 2003;Sen et al., 2000). In addition, tocopherols do not seem to share the cholesterol-lowering properties of tocotrienol (Qureshi et al., 1986; Qureshi et al., 2002). Tocotrienol, not tocopherol, administration reduces oxidative protein damage and extends the mean life span of C. elegans (Adachi and Ishii, 2000).

Furthermore, tocotrienol but not tocopherol, suppresses growth of human breast cancer cells (Nesaretnam et al., 1995). Such expanding body of evidence indicating that members of the vitamin $\mathrm{E}$ family are functionally unique calls for a revisit of the current practices in vitamin E research. Research claims should be limited to the specific form of vitamin E studied. For example, evidence for toxicity of a specific form of tocopherol in excess may not be used to conclude that high-dosage vitamin E supplementation may increase all-cause mortality (Miller et al., 2005). Along these lines, it may not be prudent to express frustrations about the net yield of vitamin E research as a whole (Greenberg, 2005) when all that has been tested for efficacy on a limited basis in clinical trials is $\alpha$-tocopherol. Vitamin $E$ represents one of the most fascinating natural resources that have the potential to influence a broad range of mechanisms underlying human health and disease. Yet, clinical outcomes studies have failed to meet expectations (Friedrich, 2004;Greenberg, 2005). The current state of knowledge warrants strategic investment into the lesser known forms of vitamin $\mathrm{E}$ with emphasis on uncovering the specific conditions that govern the function of vitamin E molecules in vivo. Outcomes studies designed in light of such information would yield lucrative returns. 


\section{Acknowledgements}

Tocotrienol research in the laboratory is supported by NIH RO1NS42617 to CKS.

\section{References}

Adachi H, Ishii N. Effects of tocotrienols on life span and protein carbonylation in Caenorhabditis elegans. Journals of Gerontology Series A, Biological Sciences \& Medical Sciences 2000;55 (6):B280-285.

Agarwal MK, Agarwal ML, Athar M, Gupta S. Tocotrienol-rich fraction of palm oil activates p53, modulates $\mathrm{Bax} / \mathrm{Bcl} 2$ ratio and induces apoptosis independent of cell cycle association. Cell Cycle 2004;3 (2):205-211. [PubMed: 14712090]

Albanes D, Heinonen OP, Taylor PR, Virtamo J, Edwards BK, Rautalahti M, Hartman AM, Palmgren J, Freedman LS, Haapakoski J, Barrett MJ, Pietinen P, Malila N, Tala E, Liippo K, Salomaa ER, Tangrea JA, Teppo L, Askin FB, Taskinen E, Erozan Y, Greenwald P, Huttunen JK. Alpha-Tocopherol and beta-carotene supplements and lung cancer incidence in the alpha-tocopherol, beta-carotene cancer prevention study: effects of base-line characteristics and study compliance. J Natl Cancer Inst 1996;88 (21):1560-1570. [PubMed: 8901854]

Anderson SL, Qiu J, Rubin BY. Tocotrienols induce IKBKAP expression: a possible therapy for familial dysautonomia. Biochemical \& Biophysical Research Communications 2003;306 (1):303-309. [PubMed: 12788105]

Bascetta E, Gunstone FD, Walton JC. Electron spin resonance study of the role of vitamin E and vitamin $\mathrm{C}$ in the inhibition of fatty acid oxidation in a model membrane. Chem Phys Lipids 1983;33 (2):207210. [PubMed: 6627532]

Begum AN, Terao J. Protective effect of alpha-tocotrienol against free radical-induced impairment of erythrocyte deformability. Bioscience, Biotechnology \& Biochemistry 2002;66 (2):398-403.

Birringer M, Pfluger P, Kluth D, Landes N, Brigelius-Flohe R. Identities and differences in the metabolism of tocotrienols and tocopherols in HepG2 cells. Journal of Nutrition 2002;132 (10):31133118. [PubMed: 12368403]

Birringer M, EyTina JH, Salvatore BA, Neuzil J. Vitamin E analogues as inducers of apoptosis: structurefunction relation. Br J Cancer 2003;88 (12):1948-1955. [PubMed: 12799642]

Black TM, Wang P, Maeda N, Coleman RA. Palm tocotrienols protect ApoE +/- mice from diet-induced atheroma formation. Journal of Nutrition 2000;130 (10):2420-2426. [PubMed: 11015467]

Boscoboinik D, Szewczyk A, Hensey C, Azzi A. Inhibition of cell proliferation by alpha-tocopherol. Role of protein kinase C. Journal of Biological Chemistry 1991;266 (10):6188-6194. [PubMed: 2007576]

Bowry VW, Mohr D, Cleary J, Stocker R. Prevention of tocopherol-mediated peroxidation in ubiquinol-10-free human low density lipoprotein. Journal of Biological Chemistry 1995;270 (11): 5756-5763. [PubMed: 7890704]

Burton GW, Ingold KU. Vitamin E as an in vitro and in vivo antioxidant. Annals of the New York Academy of Sciences 1989;570:7-22. [PubMed: 2698111]

Cahoon EB, Hall SE, Ripp KG, Ganzke TS, Hitz WD, Coughlan SJ. Metabolic redesign of vitamin E biosynthesis in plants for tocotrienol production and increased antioxidant content. Nat Biotechnol 2003;21 (9):1082-1087. [PubMed: 12897790]

Chan AC, Tran K, Raynor T, Ganz PR, Chow CK. Regeneration of vitamin E in human platelets. Journal of Biological Chemistry 1991;266 (26):17290-17295. [PubMed: 1910041]

Chao JT, Gapor A, Theriault A. Inhibitory effect of delta-tocotrienol, a HMG CoA reductase inhibitor, on monocyte-endothelial cell adhesion. J Nutr Sci Vitaminol (Tokyo) 2002;48 (5):332-337. [PubMed: 12656204]

DeCosse JJ, Miller HH, Lesser ML. Effect of wheat fiber and vitamins C and E on rectal polyps in patients with familial adenomatous polyposis. J Natl Cancer Inst 1989;81 (17):1290-1297. [PubMed: 2549261]

Elson CE, Qureshi AA. Coupling the cholesterol- and tumor-suppressive actions of palm oil to the impact of its minor constituents on 3-hydroxy-3-methylglutaryl coenzyme A reductase activity. Prostaglandins Leukotrienes \& Essential Fatty Acids 1995;52 (2-3):205-207. 
Fairus S, Rosnah MN, Cheng HM, Sundram K. Metabolic fate of palm tocotrienols in human postprandial plasma model. Asia Pac J Clin Nutr 2004;13 (Suppl):S77.

Friedrich MJ. To "E" or not to "E," vitamin E's role in health and disease is the question. Jama 2004;292 (6):671-673. [PubMed: 15304447]

Fuchs J, Kern H. Modulation of UV-light-induced skin inflammation by D-alpha-tocopherol and Lascorbic acid: a clinical study using solar simulated radiation. Free Radical Biology \& Medicine 1998;25 (9):1006-1012. [PubMed: 9870553]

Goh SH, Hew NF, Norhanom AW, Yadav M. Inhibition of tumour promotion by various palm-oil tocotrienols. International Journal of Cancer 1994;57 (4):529-531.

Gould MN, Haag JD, Kennan WS, Tanner MA, Elson CE. A comparison of tocopherol and tocotrienol for the chemoprevention of chemically induced rat mammary tumors. American Journal of Clinical Nutrition 1991;53 (4 Suppl):1068S-1070S. [PubMed: 1845366]

Green J, Bunyan J. Vitamin E and the biological antioxidant theory. Nutr Abstr Rev 1969;39 (2):321345. [PubMed: 4978332]

Greenberg ER. Vitamin E supplements: good in theory, but is the theory good? Ann Intern Med 2005;142 (1):75-76. [PubMed: 15579660]

Gu JY, Wakizono Y, Sunada Y, Hung P, Nonaka M, Sugano M, Yamada K. Dietary effect of tocopherols and tocotrienols on the immune function of spleen and mesenteric lymph node lymphocytes in Brown Norway rats. Bioscience, Biotechnology \& Biochemistry 1999;63 (10):1697-1702.

Guthrie N, Gapor A, Chambers AF, Carroll KK. Inhibition of proliferation of estrogen receptor-negative MDA-MB-435 and -positive MCF-7 human breast cancer cells by palm oil tocotrienols and tamoxifen, alone and in combination. Journal of Nutrition 1997;127 (3):544S-548S. [PubMed: 9082043]

Hartman TJ, Albanes D, Rautalahti M, Tangrea JA, Virtamo J, Stolzenberg R, Taylor PR. Physical activity and prostate cancer in the Alpha-Tocopherol, Beta-Carotene (ATBC) Cancer Prevention Study (Finland). Cancer Causes Control 1998;9 (1):11-18. [PubMed: 9486459]

Hattori A, Fukushima T, Yoshimura H, Abe K, Imai K. Production of LLU-alpha following an oral administration of gamma-tocotrienol or gamma-tocopherol to rats. Biol Pharm Bull 2000;23 (11): 1395-1397. [PubMed: 11085376]

He L, Mo H, Hadisusilo S, Qureshi AA, Elson CE. Isoprenoids suppress the growth of murine B16 melanomas in vitro and in vivo. Journal of Nutrition 1997;127 (5):668-674. [PubMed: 9164984]

Hensley K, Benaksas EJ, Bolli R, Comp P, Grammas P, Hamdheydari L, Mou S, Pye QN, Stoddard MF, Wallis G, Williamson KS, West M, Wechter WJ, Floyd RA. New perspectives on vitamin E: gammatocopherol and carboxyelthylhydroxychroman metabolites in biology and medicine. Free Radical Biology \& Medicine 2004;36 (1):1-15. [PubMed: 14732286]

Horwitt MK, Harvey CC, Duncan GD, Wilson WC. Effects of limited tocopherol intake in man with relationships to erythrocyte hemolysis and lipid oxidations. American Journal of Clinical Nutrition 1956;4 (4):408-419. [PubMed: 13339713]

Hosomi A, Arita M, Sato Y, Kiyose C, Ueda T, Igarashi O, Arai H, Inoue K. Affinity for alpha-tocopherol transfer protein as a determinant of the biological activities of vitamin $\mathrm{E}$ analogs. FEBS Letters 1997;409 (1):105-108. [PubMed: 9199513]

Ikeda I, Imasato Y, Sasaki E, Sugano M. Lymphatic transport of alpha-, gamma- and delta-tocotrienols and alpha-tocopherol in rats. International Journal for Vitamin \& Nutrition Research 1996;66 (3): 217-221. [PubMed: 8899454]

Ikeda S, Niwa T, Yamashita K. Selective uptake of dietary tocotrienols into rat skin. J Nutr Sci Vitaminol (Tokyo) 2000;46 (3):141-143. [PubMed: 10955281]

Ikeda S, Toyoshima K, Yamashita K. Dietary sesame seeds elevate alpha- and gamma-tocotrienol concentrations in skin and adipose tissue of rats fed the tocotrienol-rich fraction extracted from palm oil. Journal of Nutrition 2001;131 (11):2892-2897. [PubMed: 11694614]

Ikeda S, Tohyama T, Yoshimura H, Hamamura K, Abe K, Yamashita K. Dietary alpha-tocopherol decreases alpha-tocotrienol but not gamma-tocotrienol concentration in rats. Journal of Nutrition 2003;133 (2):428-434. [PubMed: 12566479] 
Ima-Nirwana S, Suhaniza S. Effects of tocopherols and tocotrienols on body composition and bone calcium content in adrenalectomized rats replaced with dexamethasone. J Med Food 2004;7 (1):4551. [PubMed: 15117552]

Inokuchi H, Hirokane H, Tsuzuki T, Nakagawa K, Igarashi M, Miyazawa T. Anti-angiogenic activity of tocotrienol. Bioscience, Biotechnology \& Biochemistry 2003;67 (7):1623-1627.

Iqbal J, Minhajuddin M, Beg ZH. Suppression of 7,12-dimethylbenz[alpha]anthracene-induced carcinogenesis and hypercholesterolaemia in rats by tocotrienol-rich fraction isolated from rice bran oil. Eur J Cancer Prev 2003;12 (6):447-453. [PubMed: 14639121]

Iqbal J, Minhajuddin M, Beg ZH. Suppression of diethylnitrosamine and 2-acetylaminofluorene-induced hepatocarcinogenesis in rats by tocotrienol-rich fraction isolated from rice bran oil. Eur J Cancer Prev 2004;13 (6):515-520. [PubMed: 15548946]

Kagan VE, Serbinova EA, Forte T, Scita G, Packer L. Recycling of vitamin E in human low density lipoproteins. Journal of Lipid Research 1992;33 (3):385-397. [PubMed: 1314881]

Kaku S, Yunoki S, Mori M, Ohkura K, Nonaka M, Sugano M, Yamada K. Effect of dietary antioxidants on serum lipid contents and immunoglobulin productivity of lymphocytes in Sprague-Dawley rats. Bioscience, Biotechnology \& Biochemistry 1999;63 (3):575-576.

Kamat JP, Devasagayam TP. Tocotrienols from palm oil as potent inhibitors of lipid peroxidation and protein oxidation in rat brain mitochondria. Neuroscience Letters 1995;195 (3):179-182. [PubMed: 8584204]

Kamimura M. [Physiology and clinical use of vitamin E (author's transl)]. Hokkaido Igaku Zasshi 1977;52 (3):185-188. [PubMed: 914230]

Kanaya Y, Doi T, Sasaki H, Fujita A, Matsuno S, Okamoto K, Nakano Y, Tsujiwaki S, Furuta H, Nishi M, Tsuno T, Taniguchi H, Nanjo K. Rice bran extract prevents the elevation of plasma peroxylipid in KKAy diabetic mice. Diabetes Res Clin Pract 2004;66(Suppl 1):S157-160. [PubMed: 15563968]

Khanna S, Roy S, Ryu H, Bahadduri P, Swaan PW, Ratan RR, Sen CK. Molecular basis of vitamin E action: tocotrienol modulates 12-lipoxygenase, a key mediator of glutamate-induced neurodegeneration. Journal of Biological Chemistry 2003;278 (44):43508-43515. [PubMed: 12917400]

Koba K, Abe K, Ikeda I, Sugano M. Effects of alpha-tocopherol and tocotrienols on blood pressure and linoleic acid metabolism in the spontaneously hypertensive rat (SHR). Bioscience, Biotechnology \& Biochemistry 1992;56 (9):1420-1423.

Komiyama K, lizuka K, Yamaoka M, Watanabe H, Tsuchiya N, Umezawa I. Studies on the biological activity of tocotrienols. Chemical \& Pharmaceutical Bulletin 1989;37 (5):1369-1371.

Lambelet P, Loliger J. The fate of antioxidant radicals during lipid autooxidation. I. The tocopheroxyl radicals. Chem Phys Lipids 1984;35 (3):185-198. [PubMed: 6091932]

Landes N, Pfluger P, Kluth D, Birringer M, Ruhl R, Bol GF, Glatt H, Brigelius-Flohe R. Vitamin E activates gene expression via the pregnane X receptor. Biochemical Pharmacology 2003;65 (2):269273. [PubMed: 12504802]

Liebecq, C. IUPAC-IUBMB Joint Commission on Biochemical Nomenclature and Nomenclature Commission of IUBMB. Portland Press; 1992. Biochemical Nomenclature and Related Documents.

Liede K, Hietanen J, Saxen L, Haukka J, Timonen T, Hayrinen-Immonen R, Heinonen OP. Long-term supplementation with alpha-tocopherol and beta-carotene and prevalence of oral mucosal lesions in smokers. Oral Dis 1998;4 (2):78-83. [PubMed: 9680894]

Lodge JK, Ridlington J, Leonard S, Vaule H, Traber MG. Alpha- and gamma-tocotrienols are metabolized to carboxyethyl-hydroxychroman derivatives and excreted in human urine. Lipids 2001;36 (1):4348. [PubMed: 11214728]

McIntyre BS, Briski KP, Gapor A, Sylvester PW. Antiproliferative and apoptotic effects of tocopherols and tocotrienols on preneoplastic and neoplastic mouse mammary epithelial cells. Proceedings of the Society for Experimental Biology \& Medicine 2000a;224 (4):292-301. [PubMed: 10964265]

McIntyre BS, Briski KP, Tirmenstein MA, Fariss MW, Gapor A, Sylvester PW. Antiproliferative and apoptotic effects of tocopherols and tocotrienols on normal mouse mammary epithelial cells. Lipids 2000b;35 (2):171-180. [PubMed: 10757548] 
McKeown-Eyssen G, Holloway C, Jazmaji V, Bright-See E, Dion P, Bruce WR. A randomized trial of vitamins $C$ and $E$ in the prevention of recurrence of colorectal polyps. Cancer Research 1988;48 (16): 4701-4705. [PubMed: 3293777]

Mensink RP, van Houwelingen AC, Kromhout D, Hornstra G. A vitamin E concentrate rich in tocotrienols had no effect on serum lipids, lipoproteins, or platelet function in men with mildly elevated serum lipid concentrations. American Journal of Clinical Nutrition 1999;69 (2):213-219. [PubMed: 9989682]

Miller ER 3rd, Pastor-Barriuso R, Dalal D, Riemersma RA, Appel LJ, Guallar E. Meta-analysis: highdosage vitamin E supplementation may increase all-cause mortality. Ann Intern Med 2005;142 (1): 37-46. [PubMed: 15537682]

Mireles-Rocha H, Galindo I, Huerta M, Trujillo-Hernandez B, Elizalde A, Cortes-Franco R. UVB photoprotection with antioxidants: effects of oral therapy with d-alpha-tocopherol and ascorbic acid on the minimal erythema dose. Acta Derm Venereol 2002;82 (1):21-24. [PubMed: 12013192]

Mishima K, Tanaka T, Pu F, Egashira N, Iwasaki K, Hidaka R, Matsunaga K, Takata J, Karube Y, Fujiwara M. Vitamin E isoforms alpha-tocotrienol and gamma-tocopherol prevent cerebral infarction in mice. Neuroscience Letters 2003;337 (1):56-60. [PubMed: 12524170]

Miyazawa T, Inokuchi H, Hirokane H, Tsuzuki T, Nakagawa K, Igarashi M. Anti-angiogenic potential of tocotrienol in vitro. Biochemistry (Mosc) 2004;69 (1):67-69. [PubMed: 14972020]

Mo H, Elson CE. Apoptosis and cell-cycle arrest in human and murine tumor cells are initiated by isoprenoids. Journal of Nutrition 1999;129 (4):804-813. [PubMed: 10203554]

Nafeeza MI, Fauzee AM, Kamsiah J, Gapor MT. Comparative effects of a tocotrienol-rich fraction and tocopherol in aspirin-induced gastric lesions in rats. Asia Pac J Clin Nutr 2002;11 (4):309-313. [PubMed: 12495264]

Naguib Y, Hari SP, Passwater R Jr, Huang D. Antioxidant activities of natural vitamin E formulations. J Nutr Sci Vitaminol (Tokyo) 2003;49 (4):217-220. [PubMed: 14598906]

Nakagawa K, Eitsuka T, Inokuchi H, Miyazawa T. DNA chip analysis of comprehensive food function: Inhibition of angiogenesis and telomerase activity with unsaturated vitamin $\mathrm{E}$, tocotrienol. Biofactors 2004;21 (1-4):5-10. [PubMed: 15630161]

Nesaretnam K, Guthrie N, Chambers AF, Carroll KK. Effect of tocotrienols on the growth of a human breast cancer cell line in culture. Lipids 1995;30 (12):1139-1143. [PubMed: 8614304]

Nesaretnam K, Stephen R, Dils R, Darbre P. Tocotrienols inhibit the growth of human breast cancer cells irrespective of estrogen receptor status. Lipids 1998;33 (5):461-469. [PubMed: 9625593]

Nesaretnam K, Dorasamy S, Darbre PD. Tocotrienols inhibit growth of ZR-75-1 breast cancer cells. Int J Food Sci Nutr 2000;51(Suppl):S95-103. [PubMed: 11271861]

Nesaretnam K, Ambra R, Selvaduray KR, Radhakrishnan A, Reimann K, Razak G, Virgili F. Tocotrienolrich fraction from palm oil affects gene expression in tumors resulting from MCF-7 cell inoculation in athymic mice. Lipids 2004;39 (5):459-467. [PubMed: 15506241]

Newaz MA, Nawal NN. Effect of gamma-tocotrienol on blood pressure, lipid peroxidation and total antioxidant status in spontaneously hypertensive rats (SHR). Clinical \& Experimental Hypertension (New York) 1999;21 (8):1297-1313.

Newaz MA, Yousefipour Z, Nawal N, Adeeb N. Nitric oxide synthase activity in blood vessels of spontaneously hypertensive rats: antioxidant protection by gamma-tocotrienol. J Physiol Pharmacol 2003;54 (3):319-327. [PubMed: 14566071]

Ngah WZ, Jarien Z, San MM, Marzuki A, Top GM, Shamaan NA, Kadir KA. Effect of tocotrienols on hepatocarcinogenesis induced by 2-acetylaminofluorene in rats. American Journal of Clinical Nutrition 1991;53 (4 Suppl):1076S-1081S. [PubMed: 1672785]

Noguchi N, Hanyu R, Nonaka A, Okimoto Y, Kodama T. Inhibition of THP-1 cell adhesion to endothelial cells by alpha-tocopherol and alpha-tocotrienol is dependent on intracellular concentration of the antioxidants. Free Radical Biology \& Medicine 2003;34 (12):1614-1620. [PubMed: 12788481]

Norazlina M, Ima-Nirwana S, Abul Gapor MT, Abdul Kadir Khalid B. Tocotrienols are needed for normal bone calcification in growing female rats. Asia Pac J Clin Nutr 2002;11 (3):194-199. [PubMed: 12230232]

O'Byrne D, Grundy S, Packer L, Devaraj S, Baldenius K, Hoppe PP, Kraemer K, Jialal I, Traber MG. Studies of LDL oxidation following alpha-, gamma-, or delta-tocotrienyl acetate supplementation of 
hypercholesterolemic humans. Free Radical Biology \& Medicine 2000;29 (9):834-845. [PubMed: 11063909]

Okabe M, Oji M, Ikeda I, Tachibana H, Yamada K. Tocotrienol levels in various tissues of SpragueDawley rats after intragastric administration of tocotrienols. Bioscience, Biotechnology \& Biochemistry 2002;66 (8):1768-1771.

Osakada F, Hashino A, Kume T, Katsuki H, Kaneko S, Akaike A. Alpha-tocotrienol provides the most potent neuroprotection among vitamin $\mathrm{E}$ analogs on cultured striatal neurons. Neuropharmacology 2004;47 (6):904-915. [PubMed: 15527824]

Packer L, Suzuki YJ. Vitamin E and alpha-lipoate: role in antioxidant recycling and activation of the NFkappa B transcription factor. Mol Aspects Med 1993;14 (3):229-239. [PubMed: 8264337]

Parker RA, Pearce BC, Clark RW, Gordon DA, Wright JJ. Tocotrienols regulate cholesterol production in mammalian cells by post-transcriptional suppression of 3-hydroxy-3-methylglutaryl-coenzyme A reductase. Journal of Biological Chemistry 1993;268 (15):11230-11238. [PubMed: 8388388]

Pearce BC, Parker RA, Deason ME, Qureshi AA, Wright JJ. Hypocholesterolemic activity of synthetic and natural tocotrienols. Journal of Medicinal Chemistry 1992;35 (20):3595-3606. [PubMed: 1433170]

Pearce BC, Parker RA, Deason ME, Dischino DD, Gillespie E, Qureshi AA, Volk K, Wright JJ. Inhibitors of cholesterol biosynthesis. 2. Hypocholesterolemic and antioxidant activities of benzopyran and tetrahydronaphthalene analogues of the tocotrienols. Journal of Medicinal Chemistry 1994;37 (4): 526-541. [PubMed: 8120870]

Podda M, Weber C, Traber MG, Packer L. Simultaneous determination of tissue tocopherols, tocotrienols, ubiquinols, and ubiquinones. Journal of Lipid Research 1996;37 (4):893-901. [PubMed: 8732789]

Porkkala-Sarataho E, Salonen JT, Nyyssonen K, Kaikkonen J, Salonen R, Ristonmaa U, Diczfalusy U, Brigelius-Flohe R, Loft S, Poulsen HE. Long-term effects of vitamin E, vitamin C, and combined supplementation on urinary 7-hydro-8-oxo-2'-deoxyguanosine, serum cholesterol oxidation products, and oxidation resistance of lipids in nondepleted men. Arteriosclerosis, Thrombosis \& Vascular Biology 2000;20 (9):2087-2093.

Qureshi AA, Burger WC, Peterson DM, Elson CE. The structure of an inhibitor of cholesterol biosynthesis isolated from barley. Journal of Biological Chemistry 1986;261 (23):10544-10550. [PubMed: 3733719]

Qureshi AA, Qureshi N, Hasler-Rapacz JO, Weber FE, Chaudhary V, Crenshaw TD, Gapor A, Ong AS, Chong YH, Peterson D. Dietary tocotrienols reduce concentrations of plasma cholesterol, apolipoprotein B, thromboxane B2, and platelet factor 4 in pigs with inherited hyperlipidemias. American Journal of Clinical Nutrition 1991a;53 (4 Suppl):1042S-1046S. [PubMed: 2012015]

Qureshi AA, Qureshi N, Wright JJ, Shen Z, Kramer G, Gapor A, Chong YH, DeWitt G, Ong A, Peterson DM. Lowering of serum cholesterol in hypercholesterolemic humans by tocotrienols (palmvitee). American Journal of Clinical Nutrition 1991b;53 (4 Suppl):1021S-1026S. [PubMed: 2012010]

Qureshi AA, Bradlow BA, Brace L, Manganello J, Peterson DM, Pearce BC, Wright JJ, Gapor A, Elson CE. Response of hypercholesterolemic subjects to administration of tocotrienols. Lipids 1995;30 (12):1171-1177. [PubMed: 8614309]

Qureshi AA, Mo H, Packer L, Peterson DM. Isolation and identification of novel tocotrienols from rice bran with hypocholesterolemic, antioxidant, and antitumor properties. Journal of Agricultural \& Food Chemistry 2000;48 (8):3130-3140. [PubMed: 10956081]

Qureshi AA, Peterson DM. The combined effects of novel tocotrienols and lovastatin on lipid metabolism in chickens. Atherosclerosis 2001;156 (1):39-47. [PubMed: 11368995]

Qureshi AA, Peterson DM, Hasler-Rapacz JO, Rapacz J. Novel tocotrienols of rice bran suppress cholesterogenesis in hereditary hypercholesterolemic swine. Journal of Nutrition 2001a;131 (2):223230. [PubMed: 11160537]

Qureshi AA, Salser WA, Parmar R, Emeson EE. Novel tocotrienols of rice bran inhibit atherosclerotic lesions in C57BL/6 ApoE-deficient mice. Journal of Nutrition 2001b;131 (10):2606-2618. [PubMed: 11584079]

Qureshi AA, Sami SA, Salser WA, Khan FA. Synergistic effect of tocotrienol-rich fraction (TRF(25)) of rice bran and lovastatin on lipid parameters in hypercholesterolemic humans. J Nutr Biochem 2001c;12 (6):318-329. [PubMed: 11516635] 
Qureshi AA, Sami SA, Salser WA, Khan FA. Dose-dependent suppression of serum cholesterol by tocotrienol-rich fraction (TRF25) of rice bran in hypercholesterolemic humans. Atherosclerosis 2002;161 (1):199-207. [PubMed: 11882333]

Raederstorff D, Elste V, Aebischer C, Weber P. Effect of either gamma-tocotrienol or a tocotrienol mixture on the plasma lipid profile in hamsters. Annals of Nutrition \& Metabolism 2002;46 (1):1723. [PubMed: 11914511]

Rahmat A, Ngah WZ, Shamaan NA, Gapor A, Abdul Kadir K. Long-term administration of tocotrienols and tumor-marker enzyme activities during hepatocarcinogenesis in rats. Nutrition 1993;9 (3):229232. [PubMed: 8102564]

Rapola JM, Virtamo J, Ripatti S, Huttunen JK, Albanes D, Taylor PR, Heinonen OP. Randomised trial of alpha-tocopherol and beta-carotene supplements on incidence of major coronary events in men with previous myocardial infarction. Lancet 1997;349 (9067):1715-1720. [PubMed: 9193380]

Rapola JM, Virtamo J, Ripatti S, Haukka JK, Huttunen JK, Albanes D, Taylor PR, Heinonen OP. Effects of alpha tocopherol and beta carotene supplements on symptoms, progression, and prognosis of angina pectoris. Heart 1998;79 (5):454-458. [PubMed: 9659191]

Rippert P, Scimemi C, Dubald M, Matringe M. Engineering plant shikimate pathway for production of tocotrienol and improving herbicide resistance. Plant Physiol 2004;134 (1):92-100. [PubMed: 14684842]

Roy S, Lado BH, Khanna S, Sen CK. Vitamin E sensitive genes in the developing rat fetal brain: a highdensity oligonucleotide microarray analysis. FEBS Letters 2002;530 (1-3):17-23. [PubMed: 12387859]

Saito H, Kiyose C, Yoshimura H, Ueda T, Kondo K, Igarashi O. Gamma-tocotrienol, a vitamin E homolog, is a natriuretic hormone precursor. Journal of Lipid Research 2003;44 (8):1530-1535. [PubMed: 12730299]

Sakai M, Okabe M, Yamasaki M, Tachibana H, Yamada K. Induction of apoptosis by tocotrienol in rat hepatoma dRLh-84 cells. Anticancer Research 2004;24 (3a):1683-1688. [PubMed: 15274341]

Salonen JT, Nyyssonen K, Salonen R, Lakka HM, Kaikkonen J, Porkkala-Sarataho E, Voutilainen S, Lakka TA, Rissanen T, Leskinen L, Tuomainen TP, Valkonen VP, Ristonmaa U, Poulsen HE. Antioxidant Supplementation in Atherosclerosis Prevention (ASAP) study: a randomized trial of the effect of vitamins $\mathrm{E}$ and $\mathrm{C}$ on 3-year progression of carotid atherosclerosis. J Intern Med 2000;248 (5):377-386. [PubMed: 11123502]

Schwedhelm E, Maas R, Troost R, Boger RH. Clinical pharmacokinetics of antioxidants and their impact on systemic oxidative stress. Clin Pharmacokinet 2003;42 (5):437-459. [PubMed: 12739983]

Sen CK, Khanna S, Roy S, Packer L. Molecular basis of vitamin E action. Tocotrienol potently inhibits glutamate-induced pp60(c-Src) kinase activation and death of HT4 neuronal cells. Journal of Biological Chemistry 2000;275 (17):13049-13055. [PubMed: 10777609]

Serbinova E, Kagan V, Han D, Packer L. Free radical recycling and intramembrane mobility in the antioxidant properties of alpha-tocopherol and alpha-tocotrienol. Free Radical Biology \& Medicine 1991;10 (5):263-275. [PubMed: 1649783]

Serbinova EA, Packer L. Antioxidant properties of alpha-tocopherol and alpha-tocotrienol. Methods in Enzymology 1994;234:354-366. [PubMed: 7808307]

Seward CR, Mitchell GV, Argrett LC, Hove EL. Oxidation of alpha-tocopherol to alpha-tocopheryl quinone by carbon tetrachloride-ethanol solvent. Lipids 1969;4 (6):629-630. [PubMed: 5367951]

Shah S, Gapor A, Sylvester PW. Role of caspase-8 activation in mediating vitamin E-induced apoptosis in murine mammary cancer cells. Nutrition \& Cancer 2003;45 (2):236-246. [PubMed: 12881019]

Shah S, Sylvester PW. Tocotrienol-induced caspase- 8 activation is unrelated to death receptor apoptotic signaling in neoplastic mammary epithelial cells. Exp Biol Med (Maywood) 2004;229 (8):745-755. [PubMed: 15337828]

Shun MC, Yu W, Gapor A, Parsons R, Atkinson J, Sanders BG, Kline K. Pro-apoptotic mechanisms of action of a novel vitamin $\mathrm{E}$ analog (alpha-TEA) and a naturally occurring form of vitamin $\mathrm{E}$ (deltatocotrienol) in MDA-MB-435 human breast cancer cells. Nutrition \& Cancer 2004;48 (1):95-105. [PubMed: 15203383] 
Soelaiman IN, Ahmad NS, Khalid BA. Palm oil tocotrienol mixture is better than alpha-tocopherol acetate in protecting bones against free-radical induced elevation of bone-resorbing cytokines. Asia Pac J Clin Nutr 2004;13 (Suppl):S111.

Steiner M. Vitamin E: more than an antioxidant. Clin Cardiol 1993;16 (4 Suppl 1):I16-18. [PubMed: 8472393]

Strain JJ, Mulholland CW. Vitamin C and vitamin E--synergistic interactions in vivo? Exs 1992;62:419422. [PubMed: 1450602]

Suarna C, Hood RL, Dean RT, Stocker R. Comparative antioxidant activity of tocotrienols and other natural lipid-soluble antioxidants in a homogeneous system, and in rat and human lipoproteins. Biochimica et Biophysica Acta 1993;1166 (2-3):163-170. [PubMed: 8443232]

Sundram K, Khor HT, Ong AS, Pathmanathan R. Effect of dietary palm oils on mammary carcinogenesis in female rats induced by 7,12-dimethylbenz(a)anthracene. Cancer Research 1989;49 (6):14471451. [PubMed: 2493981]

Suzuki YJ, Tsuchiya M, Wassall SR, Choo YM, Govil G, Kagan VE, Packer L. Structural and dynamic membrane properties of alpha-tocopherol and alpha-tocotrienol: implication to the molecular mechanism of their antioxidant potency. Biochemistry 1993;32 (40):10692-10699. [PubMed: 8399214]

Sylvester PW, McIntyre BS, Gapor A, Briski KP. Vitamin E inhibition of normal mammary epithelial cell growth is associated with a reduction in protein kinase C(alpha) activation. Cell Prolif 2001;34 (6):347-357. [PubMed: 11736999]

Sylvester PW, Nachnani A, Shah S, Briski KP. Role of GTP-binding proteins in reversing the antiproliferative effects of tocotrienols in preneoplastic mammary epithelial cells. Asia Pac J Clin Nutr 2002;11(Suppl 7):S452-459. [PubMed: 12492634]

Takahashi K, Loo G. Disruption of mitochondria during tocotrienol-induced apoptosis in MDA-MB-231 human breast cancer cells. Biochemical Pharmacology 2004;67 (2):315-324. [PubMed: 14698044]

Tan DT, Khor HT, Low WH, Ali A, Gapor A. Effect of a palm-oil-vitamin E concentrate on the serum and lipoprotein lipids in humans. American Journal of Clinical Nutrition 1991;53 (4 Suppl):1027S1030S. [PubMed: 2012011]

Tanito M, Itoh N, Yoshida Y, Hayakawa M, Ohira A, Niki E. Distribution of tocopherols and tocotrienols to rat ocular tissues after topical ophthalmic administration. Lipids 2004;39 (5):469-474. [PubMed: 15506242]

Tappel AL. The inhibition of hematin-catalyzed oxidations by alpha-tocopherol. Arch Biochem Biophys 1953;47 (1):223-225. [PubMed: 13114892]

Tappel AL. Studies of the mechanism of vitamin E action. II. Inhibition of unsaturated fatty acid oxidation catalyzed by hematin compounds. Arch Biochem Biophys 1954;50 (2):473-485. [PubMed: 13159347]

Tappel AL. Studies of the mechanism of vitamin E action. III. In vitro copolymerization of oxidized fats with protein. Arch Biochem 1955;54 (2):266-280. [PubMed: 14350775]

Teikari JM, Virtamo J, Rautalahti M, Palmgren J, Liesto K, Heinonen OP. Long-term supplementation with alpha-tocopherol and beta-carotene and age-related cataract. Acta Ophthalmol Scand 1997;75 (6):634-640. [PubMed: 9527321]

Teikari JM, Laatikainen L, Virtamo J, Haukka J, Rautalahti M, Liesto K, Albanes D, Taylor P, Heinonen OP. Six-year supplementation with alpha-tocopherol and beta-carotene and age-related maculopathy. Acta Ophthalmol Scand 1998;76 (2):224-229. [PubMed: 9591958]

Theriault A, Wang Q, Gapor A, Adeli K. Effects of gamma-tocotrienol on ApoB synthesis, degradation, and secretion in HepG2 cells. Arteriosclerosis, Thrombosis \& Vascular Biology 1999;19 (3):704712.

Theriault A, Chao JT, Gapor A. Tocotrienol is the most effective vitamin E for reducing endothelial expression of adhesion molecules and adhesion to monocytes. Atherosclerosis 2002;160 (1):2130. [PubMed: 11755919]

Tiahou G, Maire B, Dupuy A, Delage M, Vernet MH, Mathieu-Daude JC, Michel F, Sess ED, Cristol JP. Lack of oxidative stress in a selenium deficient area in Ivory Coast Potential nutritional antioxidant role of crude palm oil. Eur J Nutr 2004;43 (6):367-374. [PubMed: 15490200] 
Tomeo AC, Geller M, Watkins TR, Gapor A, Bierenbaum ML. Antioxidant effects of tocotrienols in patients with hyperlipidemia and carotid stenosis. Lipids 1995;30 (12):1179-1183. [PubMed: 8614310]

Traber MG, Packer L. Vitamin E: beyond antioxidant function. American Journal of Clinical Nutrition 1995;62 (6 Suppl):1501S-1509S. [PubMed: 7495251]

Traber MG, Sies H. Vitamin E in humans: demand and delivery. Annu Rev Nutr 1996;16:321-347. [PubMed: 8839930]

van Haaften RI, Haenen GR, Evelo CT, Bast A. Tocotrienols inhibit human glutathione S-transferase P1-1. IUBMB Life 2002;54 (2):81-84. [PubMed: 12440523]

Wagner KH, Kamal-Eldin A, Elmadfa I. Gamma-tocopherol--an underestimated vitamin? Annals of Nutrition \& Metabolism 2004;48 (3):169-188. [PubMed: 15256801]

Wan Nazaimoon WM, Khalid BA. Tocotrienols-rich diet decreases advanced glycosylation end-products in non-diabetic rats and improves glycemic control in streptozotocin-induced diabetic rats. Malays J Pathol 2002;24 (2):77-82. [PubMed: 12887164]

Watkins T, Lenz P, Gapor A, Struck M, Tomeo A, Bierenbaum M. gamma-Tocotrienol as a hypocholesterolemic and antioxidant agent in rats fed atherogenic diets. Lipids 1993;28 (12):11131118. [PubMed: 8121254]

Weber SU, Thiele JJ, Han N, Luu C, Valacchi G, Weber S, Packer L. Topical alpha-tocotrienol supplementation inhibits lipid peroxidation but fails to mitigate increased transepidermal water loss after benzoyl peroxide treatment of human skin. Free Radical Biology \& Medicine 2003;34 (2): 170-176. [PubMed: 12521598]

Woodson K, Albanes D, Tangrea JA, Rautalahti M, Virtamo J, Taylor PR. Association between alcohol and lung cancer in the alpha-tocopherol, beta-carotene cancer prevention study in Finland. Cancer Causes Control 1999;10 (3):219-226. [PubMed: 10454067]

Yamashita K, Ikeda S, Iizuka Y, Ikeda I. Effect of sesaminol on plasma and tissue alpha-tocopherol and alpha-tocotrienol concentrations in rats fed a vitamin E concentrate rich in tocotrienols. Lipids 2002;37 (4):351-358. [PubMed: 12030315]

Yap SP, Yuen KH, Wong JW. Pharmacokinetics and bioavailability of alpha-, gamma- and deltatocotrienols under different food status. J Pharm Pharmacol 2001;53 (1):67-71. [PubMed: 11206194]

Yap SP, Yuen KH, Lim AB. Influence of route of administration on the absorption and disposition of alpha-, gamma- and delta-tocotrienols in rats. J Pharm Pharmacol 2003;55 (1):53-58. [PubMed: 12625867]

Yoshida Y, Niki E, Noguchi N. Comparative study on the action of tocopherols and tocotrienols as antioxidant: chemical and physical effects. Chem Phys Lipids 2003;123 (1):63-75. [PubMed: 12637165]

Yu W, Simmons-Menchaca M, Gapor A, Sanders BG, Kline K. Induction of apoptosis in human breast cancer cells by tocopherols and tocotrienols. Nutrition \& Cancer 1999;33 (1):26-32. [PubMed: 10227040]

Zalkin H, Tappel AL. Studies of the mechanism of vitamin E action. IV. Lipide peroxidation in the vitamin E-deficient rabbit. Arch Biochem Biophys 1960;88:113-117. [PubMed: 13846891]

Zalkin H, Tappel AL, Jordan JP. Studies of the mechanism of vitamin E action. V. Selenite and tocopherol inhibition of lipid peroxidation in the chick. Arch Biochem Biophys 1960;91:117-122. [PubMed: 13787781]

Zhou C, Tabb MM, Sadatrafiei A, Grun F, Blumberg B. Tocotrienols activate the steroid and xenobiotic receptor, SXR, and selectively regulate expression of its target genes. Drug Metab Dispos 2004;32 (10):1075-1082. [PubMed: 15269186]

Zingg JM, Azzi A. Non-antioxidant activities of vitamin E. Curr Med Chem 2004;11 (9):1113-1133. [PubMed: 15134510] 

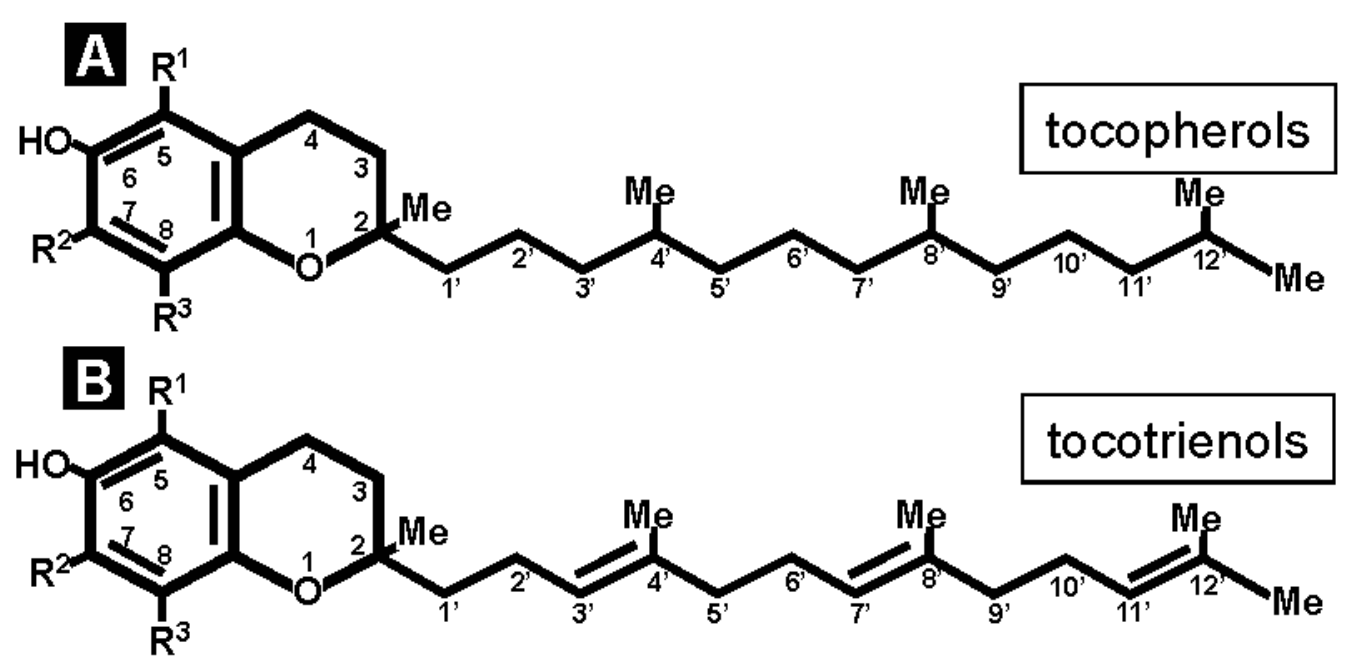

Figure 1. Vitamin E: variations and nomenclature

A, R1 = R2 = R3 = Me, known as $\alpha$-tocopherol, is designated $\alpha$-tocopherol or 5,7,8trimethyltocol; R1 = R3 = Me; R2 = H, known as, $\beta$-tocopherol, is designated, $\beta$-tocopherol or 5,8-dimethyltocol; R1 = H; R2=R3 = Me, known as $\gamma$-tocopherol, is designated $\gamma$-tocopherol or 7,8-dimethyltocol; R1 $=\mathrm{R} 2=\mathrm{H} ; \mathrm{R} 3=\mathrm{Me}$, known as $\delta$-tocopherol, is designated $\delta$-tocopherol or 8-methyltocol. B, R1 = R2 = R3 = H, 2-methyl-2-(4,8,12-trimethyltrideca-3,7,11-trienyl) chroman-6-ol, is designated tocotrienol; R1 = R2 = R3 = Me, formerly known as $\zeta 1$ or $\zeta 2-$ tocopherol, is designated 5,7,8-trimethyltocotrienol or $\alpha$-tocotrienol. The name tocochromanol-3 has also been used; R1 = R3 = Me; R2 = H, formerly known as $\varepsilon$-tocopherol, is designated 5,8-dimethyltocotrienol or $\beta$-tocotrienol; R1 = H; R2 = R3 = Me, formerly known as $\gamma$-tocopherol, is designated 7,8-dimethyltocotrienol or $\gamma$-tocotrienol. The name plastochromanol-3 has also been used; R1 = R2 = H; R3 = Me is designated 8-methyltocotrienol or $\delta$-tocotrienol (Liebecq, 1992). 
Table 1

TOCOTRIENOL: A NEW FACE OF VITAMIN E UNFLODING

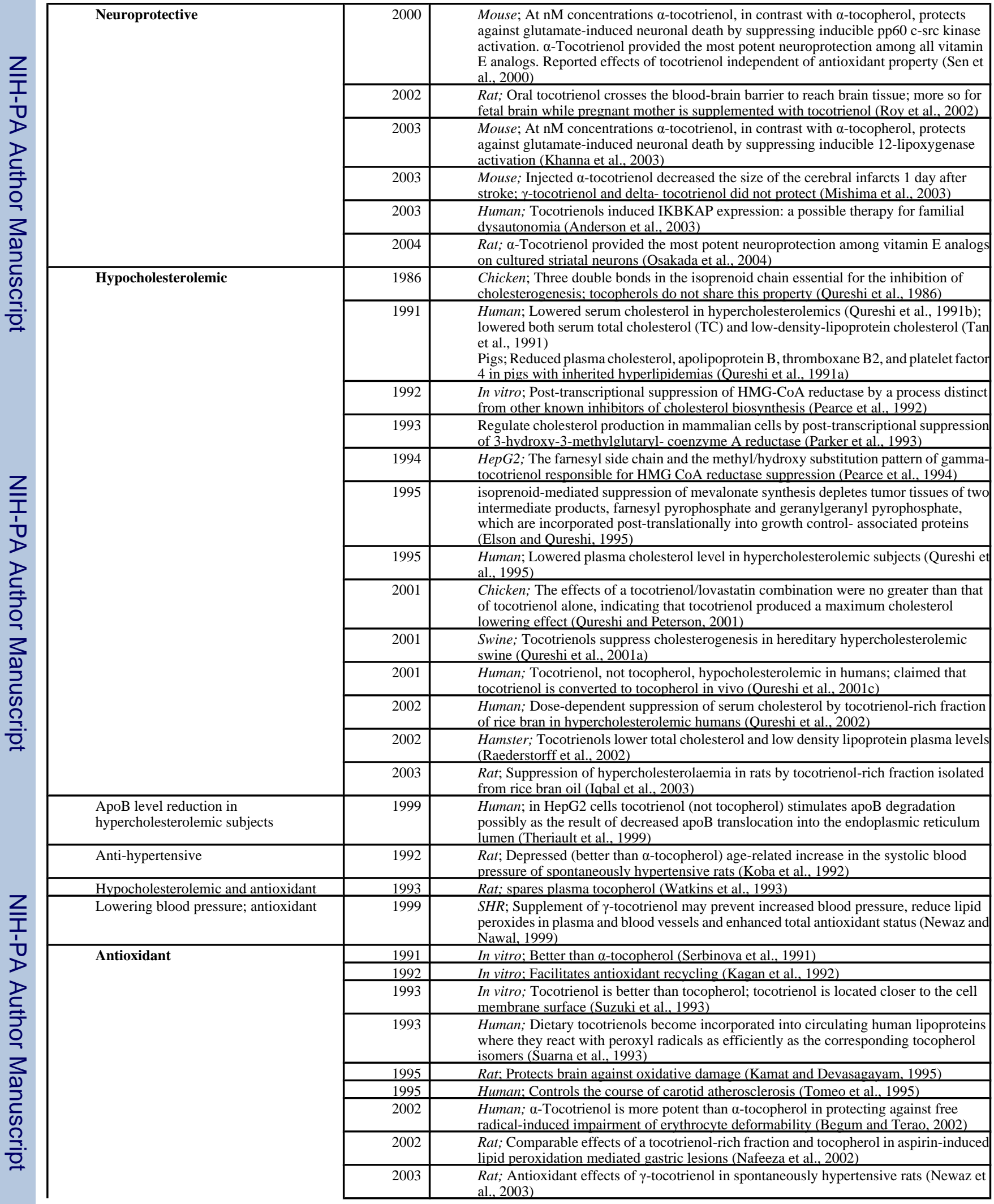




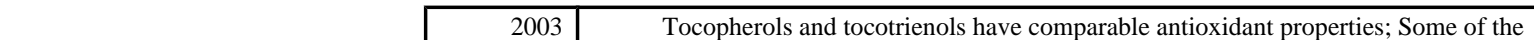
vitamin $\mathrm{E}$ formulations tested showed antioxidant activities superior to d-alphatocopherol (Naguib et al.. 2003)

\begin{tabular}{|c|c|}
\hline 2003 & $\begin{array}{l}\text { The corresponding tocopherols and tocotrienols exert comparable antioxidant activity; } \\
\text { tocotrienols are more readily transferred between the membranes and incorporated into } \\
\text { the membranes than tocopherols (Yoshida et al.. 2003) }\end{array}$ \\
\hline 2003 & Human; Topical $\alpha$-tocotrienol supplementation inhibits lipid peroxidation in human skin \\
\hline
\end{tabular}

\begin{tabular}{|c|c|}
\hline 2003 & $\begin{array}{l}\text { The corresponding tocopherols and tocotrienols exert comparable antioxidant activity; } \\
\text { tocotrienols are more readily transferred between the membranes and incorporated into } \\
\text { the membranes than tocopherols (Yoshida et al.. 2003) }\end{array}$ \\
\hline 2003 & Human; Topical $\alpha$-tocotrienol supplementation inhibits lipid peroxidation in human skin \\
\hline
\end{tabular}

\begin{tabular}{|c|c|}
\hline 2003 & $\begin{array}{l}\text { The corresponding tocopherols and tocotrienols exert comparable antioxidant activity; } \\
\text { tocotrienols are more readily transferred between the membranes and incorporated into } \\
\text { the membranes than tocopherols (Yoshida et al.. 2003) }\end{array}$ \\
\hline 2003 & Human; Topical $\alpha$-tocotrienol supplementation inhibits lipid peroxidation in human skin \\
\hline
\end{tabular} (Weber et al., 2003)

2004 Human; Lack of oxidative stress in a selenium deficient area in Ivory Coast Potential nutritional antioxidant role of crude palm oil (Tiahou et al., 2004) $2004 \begin{aligned} & \text { Rat; Palm oil tocotrienol mixture better than } \alpha \text {-tocopherol acetate in protecting bones } \\ & \text { against free-radical induced elevation of bone-resorbing cytokines (Soelaiman et al., }\end{aligned}$

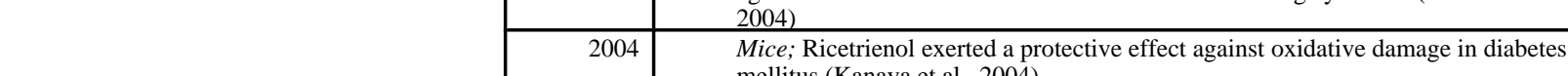

Antiaging/antioxidant mellitus (Kanaya et al., 2004)

2000 C. elegans; Tocotrienol, not tocopherol, administration reduced the accumulation of protein carbonyl and consequently extended the mean life span but not the maximum life span (Adachi and Ishii, 2000).

Anti-cancer

\begin{tabular}{c|l|}
1989 & $\begin{array}{l}\text { Mouse } \text { Intraperitoneally injected tocotrienol prevented transplanted tumors (Komiyama } \\
\text { et al., 1989) }\end{array}$ \\
\hline 1989 & Rat; Tocotrienol-rich palm oil prevented chemically-induced mammary tumorigenesis \\
\hline
\end{tabular}

\begin{tabular}{c|c|}
1989 & $\begin{array}{l}\text { Mouse } \text { Intraperitoneally injected tocotrienol prevented transplanted tumors (Komiyama } \\
\text { et al., 1989) }\end{array}$ \\
\hline 1989 & Rat; Tocotrienol-rich palm oil prevented chemically-induced mammary tumorigenesis \\
\hline
\end{tabular} (Sundram et al., 1989)

1991 Rat; Tocotrienol., but not tocopherol, was chemopreventive in mammary tumor model (Gould et al., 1991)

1991 Rat; Tocotrienol. chemopreventive in hepatic tumor model (Ngah et al.. 1991)

1993 Rat; Tocotrienol. chemopreventive in hepatic tumor model (Rahmat et al., 1993)

1994 Human; Suppresses activation of Epstein-Barr virus early antigen expression in PMAactivated lymphoblastoid Raji cells (Goh et al., 1994)

1995 Human; Tocotrienol, not tocopherol, suppresses growth of a human breast cancer cell line in culture (Nesaretnam et al., 1995)

1997 Human; Inhibited proliferation of estrogen receptor-negative MDA-MB-435 and positive MCF-7 breast cancer cells (Guthrie et al., 1997)

Mouse; Isoprenoids suppress the growth of murine B16 melanomas in vitro and in vivo (He et al., 1997)

1998 Human; Inhibit the growth of human breast cancer cells irrespective of estrogen receptor status (Nesaretnam et al., 1998)

1999 Human; Apoptosis and cell-cycle arrest in human and murine tumor cells are initiated by isoprenoids (Mo and Elson, 1999)

1999 Human; Naturally occurring tocotrienols and RRR- $\delta$-tocopherol are effective apoptotic inducers for human breast cancer cells (Yu et al.. 1999)

2000 Human; Tocotrienols inhibit growth of ZR-75-1 breast cancer cells (Nesaretnam et al. 2000)

$2000 \quad$ Mouse; Highly potent $\gamma$ - and $\delta$-tocotrienol isoforms may play a physiological role in modulating normal mammary gland growth, function, and remodeling (McIntyre et al 2000b)

2000 Mouse; highly malignant breast cancer cells were the most sensitive, whereas the preneoplastic cells were the least sensitive to the antiproliferative and apoptotic effect of tocotrienols (McIntyre et al., 2000a)

2001 Mouse; Tocotrienols are significantly more potent than tocopherols in suppressing EGFdependent normal mammary epithelial cell growth. The inhibitory effects of specific tocopherol and tocotrienol isoforms on EGF-dependent normal mammary epithelial cell mitogenesis occurs downstream from the EGF-receptor and appears to be mediated, at least in part, by a reduction in PKC $\alpha$ activation (Sylvester et al., 2001)

002 Mouse; Antiproliferative effects of tocotrienols in preneoplastic mammary epithelial cells do not reflect a reduction in EGF- receptor mitogenic responsiveness, but rather, result from an inhibition in early post-receptor events involved in cAMP production upstream from EGF-dependent MAPK and phosphoinositide 3-kinase/Akt mitogenic signaling (Sylvester et al., 2002)

\begin{tabular}{|r|r|} 
& $\begin{array}{l}\text { 2ells do not reflect a reduction in EGF- receptor mitogenic responsiveness, but rather, } \\
\text { result from an inhibition in early post-receptor events involved in cAMP production } \\
\text { upstream from EGF-dependent MAPK and phosphoinositide 3-kinase/Akt mitogenic } \\
\text { signaling (Sylvester et al., 2002) }\end{array}$ \\
\hline 2003 & $\begin{array}{l}\text { Rat; } \text { Suppression of 7,12-dimethylbenz[alpha]anthracene-induced carcinogenesis by } \\
\text { tocotrienol-rich fraction isolated from rice bran oil (Iqbal et al., 2003) }\end{array}$ \\
\hline 2003 & $\begin{array}{l}\text { Mouse; Tocotrienol-induced apoptosis in mammary cancer cells is mediated through } \\
\text { activation of the caspase-8 signaling pathway and is independent of caspase-9 activation } \\
\text { (Shah et al., 2003) }\end{array}$ \\
\hline 2004 & $\begin{array}{l}\text { Mouse; Tocotrienol-induces caspase-8 activation, unrelated to death receptor apoptotic } \\
\text { signaling, in neoplastic mammary epithelial cells (Shah and Sylvester, 2004) }\end{array}$ \\
\hline 2004 & $\begin{array}{l}\text { Rat; Tocotrienol induces apoptosis in dRLh-84 hepatoma cells (Sakai et al., 2004) } \\
\text { and 2-acetylaminofluorene-induced hepatocarcinogenesis (Iqbal et al., 2004) }\end{array}$ \\
\hline 2004 & $\begin{array}{l}\text { Human; Tocotrienol disrupts mitochondrial function and causes apoptosis of breast } \\
\text { cancer cells (Takahashi and Loo, 2004) }\end{array}$ \\
\hline 2004 & $\begin{array}{l}\text { Human; Pro-apoptotic properties of } \delta \text {-tocotrienol) in breast cancer cells (Shun et al., } \\
\text { 2004) }\end{array}$ \\
\hline 2004 & $\begin{array}{l}\text { Human; Supplementation of tocotrienol rich fraction of palm oil significantly and } \\
\text { specifically affected MCF-7 cell response after tumor formation in vivo by an } \\
\text { antioxidant-independent mechanism (Nesaretnam et al., 2004) }\end{array}$ \\
\hline
\end{tabular}




\begin{tabular}{|c|c|c|}
\hline & 2004 & $\begin{array}{l}\text { Human; Tocotrienol-rich fraction of palm oil activated p53, modulated Bax/Bcl2 ratio } \\
\text { and induced apoptosis independent of cell cycle association in colorectal cancer RKO } \\
\text { cells (Agarwal et al.. 2004) }\end{array}$ \\
\hline $\begin{array}{l}\text { Modulating normal mammary gland } \\
\text { growth, function, and remodeling }\end{array}$ & 2000 & $\begin{array}{l}\text { Mouse; Mammary epithelial cells more easily or preferentially took up tocotrienols as } \\
\text { compared to tocopherols (McIntyre et al.. 2000b) }\end{array}$ \\
\hline \multirow[t]{3}{*}{ Antiangiogenic } & 2004 & $\begin{array}{l}\text { Human/Chicken; Tocotrienol, not tocopherol, inhibited angiogenesis and telomerase } \\
\text { activity (Nakagawa et al.. 2004) }\end{array}$ \\
\hline & 2004 & $\begin{array}{l}\text { Bovine; Tocotrienol, not tocopherol, limited angiogenic responses in vitro (Miyazawa } \\
\text { et al.. 2004) }\end{array}$ \\
\hline & 2003 & $\begin{array}{l}\text { Bovine; Tocotrienol, but not tocopherol, inhibited both the proliferation and tube } \\
\text { formation of aortic endothelial cells (Inokuchi et al., 2003) }\end{array}$ \\
\hline \multirow[t]{2}{*}{ Antiproliferative and apoptotic } & 2000 & $\begin{array}{l}\text { Mouse; Preneoplastic and neoplastic mammary epithelial cells: } \alpha \text { - and } \gamma \text {-tocopherol had } \\
\text { no effect on cell proliferation (McIntyre et al., 2000a) }\end{array}$ \\
\hline & 2003 & $\begin{array}{l}\text { Cancer cell lines; Not } \alpha \text {-tocotrienol but } \gamma \text {-tocotrienol was apoptogenic, and more so } \\
\text { when succinylated. Shortening the aliphatic side chain of gamma-tocotrienol by one } \\
\text { isoprenvl unit increased its activity (Birringer et al.. 2003) }\end{array}$ \\
\hline $\begin{array}{l}\text { Hypocholesterolemic, antioxidant \& } \\
\text { antitumor }\end{array}$ & 2000 & $\begin{array}{l}\text { Chicken; The number and position of methyl substituents in tocotrienols affect their } \\
\text { hypocholesterolemic, antioxidant, and antitumor properties; tocotrienol better than } \alpha \text { - } \\
\text { tocopherol (Qureshi et al., 2000) }\end{array}$ \\
\hline \multirow[t]{2}{*}{ Anti-atherogenic } & 2001 & $\begin{array}{l}\text { Mouse; Palm tocotrienols protect ApoE }+/- \text { mice from diet-induced atheroma formation } \\
\text { (Black et al. 2000) }\end{array}$ \\
\hline & 2001 & $\begin{array}{l}\text { Mouse; Tocotrienols inhibit atherosclerotic lesions in ApoE-deficient mice (Qureshi et } \\
\text { al. 2001b) }\end{array}$ \\
\hline Serum lipoproteins; platelet function & 1999 & $\begin{array}{l}\text { Human; in men at risk for cardiovascular disease tocotrienol supplements used had no } \\
\text { marked favorable effects (Mensink et al.. 1999) }\end{array}$ \\
\hline \multirow[t]{3}{*}{ Anti-inflammatory } & 2002 & Human: Tocotrienols inhibit monocyte-endothelial cell adhesion (Chao et al.. 2002) \\
\hline & 2002 & $\begin{array}{l}\text { Human; Tocotrienol is the most effective vitamin E for reducing endothelial expression } \\
\text { of adhesion molecules and adhesion to monocytes (Theriault et al., 2002) }\end{array}$ \\
\hline & 2003 & $\begin{array}{l}\text { Human; The efficacy of tocotrienol for reduction of VCAM-1 expression and adhesion } \\
\text { of THP-1 cells to HUVECs was 10- fold higher than that of tocopherol (Noguchi et al., } \\
2003 \text { ) }\end{array}$ \\
\hline Serum triglycerides & 1999 & $\begin{array}{l}\text { Rat; Lower in tocotrienol fed; higher IgM productivity of spleen lymphocytes and IgA, } \\
\text { IgG, and higher IgM productivity mesenteric lymph node lymphocytes (Kaku et al., } \\
\text { 1999) }\end{array}$ \\
\hline Immune function & 1999 & $\begin{array}{l}\text { Rats; Feeding affects proliferation and function of spleen and mesenetric lymph node } \\
\text { lymphocytes (Gu et al., 1999) }\end{array}$ \\
\hline Transfer Protein & 1997 & $\begin{array}{l}\alpha \text {-Tocopherol transfer protein binds } \alpha \text {-tocotrienol with } 11 \% \text { efficiency compared to } \alpha \text { - } \\
\text { tocopherol (Hosomi et al.. 1997) }\end{array}$ \\
\hline Lymphatic transport & 1996 & $\begin{array}{l}\text { Rat; preferential absorption of } \alpha \text {-tocotrienol compared to } \gamma-\text { and } \delta \text {-tocotrienols and } \alpha \text { - } \\
\text { tocopherol (Ikeda et al.. 1996) }\end{array}$ \\
\hline \multirow[t]{3}{*}{ Drug metabolism } & 2002 & Tocotrienols inhibit human glutathione S-transferase P1-1 (van Haaften et al., 2002) \\
\hline & 2003 & $\begin{array}{l}\text { Human; Vitamin } \mathrm{E} \text { are able to activate gene expression via the pregnane } \mathrm{X} \text { receptor } \\
\text { (PXR), a nuclear receptor regulating a variety of drug metabolizing enzymes. } \\
\text { Tocotrienols more potent than tocopherols (Landes et al.. 2003) }\end{array}$ \\
\hline & 2004 & $\begin{array}{l}\text { In vitro; Tocotrienols activate the steroid and xenobiotic receptor, SXR, and selectively } \\
\text { regulate expression of its target genes (Zhou et al.. 2004) }\end{array}$ \\
\hline Eye & 2004 & $\begin{array}{l}\text { Rat; Preferential uptake of topically applied tocotrienol, over tocopherol, by ocular } \\
\text { tissues (Tanito et al.. 2004) }\end{array}$ \\
\hline Bone & 2002 & $\begin{array}{l}\text { Rat; Tocotrienols are needed for normal bone calcification in growing female rats } \\
\text { (Norazlina et al. 2002) }\end{array}$ \\
\hline Obesity \& Osteoporosis & 2004 & $\begin{array}{l}\text { Rat; Tocotrienol, not tocopherol, has the potential to be utilized as a prophylactic agent } \\
\text { in preventing side effects of long- term glucocorticoid use (Ima-Nirwana and Suhaniza, } \\
\text { 2004) }\end{array}$ \\
\hline Diabetes & 2002 & $\begin{array}{l}\text { Rat; Tocotrienols-rich diet decreased advanced glycosylation end-products in non- } \\
\text { diabetic rats and improved glycemic control in streptozotocin-induced diabetic rats (Wan } \\
\text { Nazaimoon and Khalid, 2002) }\end{array}$ \\
\hline \multirow[t]{2}{*}{ Natriuretic function } & 2000 & $\begin{array}{l}\text { Rat; An oral administration of } \gamma \text {-tocotrienol increases plasma concentration of 2,7,8- } \\
\text { trimethyl-2-(beta-carboxyethyl)-6- hydroxy chroman (LLU-alpha, gamma-CEHC), a } \\
\text { natriuretic compound (Hattori et al., 2000) }\end{array}$ \\
\hline & 2003 & Rat; $\gamma$-Tocotrienol is a natriuretic hormone precursor (Saito et al., 2003) \\
\hline \multirow[t]{7}{*}{ Bioavailability } & 1996 & $\begin{array}{l}\text { Mouse; Supplemented tocotrienol not detected in the brain (Podda et al., 1996). See } \\
2002 * \text { below. }\end{array}$ \\
\hline & 2000 & $\begin{array}{l}\text { Human; Following supplementation, } \sim 1 \mu \mathrm{M} \text { tocotrienol detected in human plasma } \\
\left(\mathrm{O}^{\prime} \text { Byrne et al., 2000) }\right.\end{array}$ \\
\hline & 2000 & $\begin{array}{l}\text { Rat; The skin is a unique tissue in respect to its ability to discriminate between various } \\
\text { vitamin E analogs; it preferentially uptakes dietary tocotrienols (Ikeda et al., 2000) }\end{array}$ \\
\hline & 2001 & $\begin{array}{l}\text { Humans; Increased absorption of the tocotrienols in the fed versus fasted state (Yap et } \\
\text { al., 2001) }\end{array}$ \\
\hline & 2001 & $\begin{array}{l}\text { Humans; Tocotrienols, like tocopherols, are metabolized to CEHC; however, the } \\
\text { quantities excreted in human urine are small in relation to dose size (Lodge et al., } \\
\text { 2001) }\end{array}$ \\
\hline & 2001 & $\begin{array}{l}\text { Rat; Dietary sesame seeds elevate the tissue concentrations of orally taken tocopherols } \\
\text { and tocotrienols (Ikeda et al., 2001) }\end{array}$ \\
\hline & $2002^{*}$ & $\begin{array}{l}\text { Rat; Oral tocotrienol crosses the blood-brain barrier to reach brain tissue; more so for } \\
\text { fetal brain while pregnant mother is supplemented with tocotrienol (Roy et al., 2002) }\end{array}$ \\
\hline
\end{tabular}




\begin{tabular}{|c|c|}
\hline 2002 & $\begin{array}{l}\text { Human; In HepG2 cells, tocotrienols are metabolized essentially like tocopherols, i.e., } \\
\text { by } \beta \text {-oxidation followed by } \beta \text { - oxidation of the side chain. Quantitatively, tocotrienols } \\
\text { are degraded to a larger extent than tocopherols (Birringer et al.. 2002) }\end{array}$ \\
\hline 2002 & $\begin{array}{l}\text { Rat; Sesame lignans added to diet increased plasma and tissue concentrations of } \\
\text { supplemented tocotrienols (Yamashita et al.. 2002) }\end{array}$ \\
\hline 2002 & $\begin{array}{l}\text { Rat; In epididymal adipose, renal adipose, subcutaneous adipose and brown adipose } \\
\text { tissues and in the heart, the tocotrienol levels were maintained or increased for } 24 \mathrm{~h} \text { after } \\
\text { intragastric administration. In the serum, liver, mesenteric lymph node, spleen and lungs, } \\
\text { the tocotrienol levels were highest } 8 \mathrm{~h} \text { after the administration (Okabe et al., 2002) }\end{array}$ \\
\hline 2003 & $\begin{array}{l}\text { Rat; Dietary } \alpha \text {-tocopherol decreases } \alpha \text {-tocotrienol but not } \gamma \text {-tocotrienol concentration in } \\
\text { rats (Ikeda et al., 2003) }\end{array}$ \\
\hline 2003 & $\begin{array}{l}\text { Tocotrienols are more readily transferred between the membranes and incorporated into } \\
\text { the membranes than tocopherols (Yoshida et al., 2003) }\end{array}$ \\
\hline 2003 & $\begin{array}{l}\text { Human; } \alpha \text {-Tocotrienol accumulate in endothelial cells to levels approximately } 10 \text {-fold } \\
\text { greater than that of } \alpha \text {-tocopherol (Noguchi et al.. 2003) }\end{array}$ \\
\hline 2003 & $\begin{array}{l}\text { Rat; Of the three tocotrienols, } \alpha \text {-tocotrienol had the highest oral bioavailability, at about } \\
27.7+/-9.2 \% \text {, compared with } \gamma-\text { and } \delta \text {-tocotrienols, which had values of } 9.1+/-2.4 \% \\
\text { and } 8.5+/-3.5 \% \text {, respectively. Tocotrienols were found to be negligibly absorbed when } \\
\text { administered intraperitoneally and intramuscularly (Yap et al., 2003) }\end{array}$ \\
\hline 2003 & $\begin{array}{l}\text { Human; The } \mathrm{t}_{1 / 2} \text { of tocotrienols is short, ranging from } 3.8-4.4 \mathrm{~h} \text { for } \gamma-\text { and } \alpha \text {-tocotrienol } \\
\text { (Schwedhelm et al., 2003) }\end{array}$ \\
\hline 2004 & $\begin{array}{l}\text { Human; Following the intervention with palm vitamin E, tocotrienols are detected in } \\
\text { total blood plasma, TRP, LDL and HDL. Tocotrienols appeared in the blood stream at } \\
2 \mathrm{~h} \text { interval \& disappeared within } 24 \mathrm{~h} \text {. Tocotrienols concentration in total plasma plasma, } \\
\text { TRP \& LDL peaked between } 4 \text { to } 6 \mathrm{~h} \text {; in HDL, tocotrienol concentrations peaked at } 8 \mathrm{~h} \\
\text { after supplementation. } \alpha \text {-tocopherol was the major vitamin E detected in plasma. } \\
\text { Tocotrienols have a very short duration of absorption \& distribution in circulating blood } \\
\text { (Fairus et al., 2004). }\end{array}$ \\
\hline
\end{tabular}

CEHC, carboxyethyl-hydroxychromans; EGF, epidermal growth factor; HDL, high density lipoprotein; HMG CoA reductase, 3-hydroxy-3-methylglutaryl coenzyme A reductase; HUVEC, human umbilical vein (derived) endothelial cells; IKBKAP, gene encoding IkappaB kinase complex-associated protein; LDL, low density lipoprotein; SHR, spontaneously hypertensive rats; TRP, triglyceride rich particles. 